\title{
Dimensions and Correlates of Development in Construction
}

\author{
*André Ullal and Paolo Tombesi
}

First submission: 25 March 2020; Accepted: 7 September 2020; Published: 8 December 2021

To cite this article: André Ullal and Paolo Tombesi (2021). Dimensions and correlates of development in construction. Journal of Construction in Developing Countries, 26(2): 37-64. https://doi.org/10.21315/jcdc2021.26.2.3.

To link to this article: https://doi.org/10.21315/jcdc2021.26.2.3

\begin{abstract}
In light of the limited impact research on construction in developing countries has had on theory and practice, this article discusses the meaning of development as it pertains to construction. The discussion distinguishes between studies addressing construction in developing countries, entailing focus on context and case-based approaches to research, and studies that focus on the process of construction industry development. Progress in research addressing the process of development has been hampered by a lack of data to support the examination of changes in construction industries over time and to compare industries in countries at different stages of economic development. To encourage more process-oriented research, a definition of development in construction is elaborated to include six important dimensions - i.e., important factors affecting construction industry development. Taking into account the lack of relevant statistics, correlates for these dimensions (i.e., statistical proxies) are reviewed. Finally, a manner of graphically presenting these dimensions and correlates is introduced. This graphic format enables visual comparison of conditions affecting construction in different countries. It also provides a frame for relating separate case studies to support comparisons and contributions to theory.
\end{abstract}

Keywords: Construction industry, Developing countries, Industry development, Industrial statistics, Industry case studies

\section{INTRODUCTION}

Current discourse has highlighted a lack of progress in the academic field that addresses construction in developing countries, specifically with regard to the limited advancement of theories and the limited contributions of academia to practice (Ofori, 2018; 2019; Chan, 2019). Such discourse has inter alia questioned the appropriateness of transferring research approaches and conceptual frames from the subject of developed countries to that of developing countries. The discourse has also questioned the appropriateness of the bipolar distinction between developing and developed countries. This article contributes to the discussion by considering what "development" means in relation to construction. It identifies critical dimensions related to construction industry development and, in light of a lack of directly relevant statistics, it reviews potential correlates that could enable measurement along these dimensions. Through measurement and subsequent comparison of conditions surrounding construction industries in different countries, country-specific studies can be positioned within a broader analytical frame. This framing of case-based studies could support contributions to

School of Architecture, Civil and Environmental Engineering, Ecole Polytechnique Fédérale de Lausanne, Lausanne, SWITZERLAND

*Corresponding author: andre.ullal@epfl.ch 
new theories and concepts relating the process of development in construction to broader trajectories of national economic development.

Study of the construction industry in developing countries is well-established as a subject of inquiry within the field of construction management and economics. Since the 1970s, a body of literature addressing various topics related to the subject has been published in leading academic journals. A journal dedicated to the subject-the Journal of Construction in Developing Countries-was inaugurated in 2005. Construction industry development has also been the subject of numerous academic conferences, symposia and commissions, including the CIB's (International Council for Research and Innovation in Building and Construction) Working Commission W107 on Construction in Developing Countries.' These publications and forums have engaged a community of scholars in various topics and discourses.

CIB Working Commission W107 has proposed an ambitious agenda for research and policy development regarding construction industries in developing countries (Rwelamila and Ogunlana, 2015). The agenda proposes very broad research topics and industrial requirements that may be grouped thematically into: (1) Identification of appropriate frameworks of development that account for sustainability, urbanisation and gender equality, (2) Definition of appropriate modes of technology that respond to local resource availability and vernacular knowledge and (3) Formulation and adaptation of appropriate governance mechanisms for financing, procurement, project management and industry support.

Despite this attention, research on the subject has had limited impact upon theory about, and practice of, construction management. Typically, studies on the subject have applied theories and concepts about construction in moredeveloped countries to less-developed contexts, highlighting problematic conditions and practices and their implications for industrial capabilities. Industrial constraints regularly identified in studies include: (1) Limited managerial expertise, (2) Inadequate access to credit for construction firms, (3) Inappropriate or poorly implemented regulations and (4) Widespread prevalence of corruption. However, the impact of knowledge about problematic conditions and practices has been limited, as exemplified in the continued prevalence of standard arrangements of construction procurement and contracting in developing countries despite widespread recognition in the literature of adverse conditions and negative implications for industry development (Ofori, 2006). Furthermore, little progress has been made in understanding how construction firms and industries change in relation to broader processes of national economic development. How do industrial constraints evolve and what factors are associated with their amelioration? How do different institutional arrangements affect construction industry development? How have new construction technologies been disseminated within developing countries and what are the impacts of these technologies upon productivity? Many aspects of the relationship between the "processes" of economic development and construction industry development remain unexplored.

Limited advances in the study of construction industry development may be attributed to a lack of statistical data to compare construction industries in different countries. Value added by construction (VAC) is typically recorded in national accounts as a component of gross domestic product (GDP). Statistics recording employment in construction are also available for a wide range of 
countries. These statistics have been used in numerous comparative studies of industry development (e.g., Turin, 1978; Bon, 1992; Wells, 1984; Crosthwaite, 2000; Ruddock and Lopes, 2006; Choy, 2011). Industrial input-output statistics have been used to investigate construction productivity in developed economies and in several developing economies, including Turkey (Bon, Birgonul and Ozdogan, 1999) and the BRICS nations, comprising Brazil, Russia, Indonesia, China and South Africa (Gregori and Pietroforte, 2018). However, statistics describing aspects of production and output of construction industries are typically not available for countries at earlier stages of development, as their systems of national statistical accounting are less sophisticated. ${ }^{2}$

Another significant handicap on progress in theory advancement and contributions to practice lies in the semantic foundations of the subject. It is useful to distinguish between the study of "construction in developing countries" vis-ávis "construction industry development". Construction in developing countries focusses attention on the category of developing countries, defined in relation to the other group of countries that are more developed. Construction industry development focusses attention on the process of change. Although the difference between these two semantic positions may not seem critical, as Turin (2003: 180) suggested "semantic difficulties are often revealing of deeper conceptual problems". These two semantic positions (i.e., focussing either on development categories or on development processes) are both represented in the body of published literature on the subject.

The first semantic position is reflected in the majority of literature on the subject, which apply concepts formulated in relation to developed countries to the other category of developing countries. Many studies in this group-particularly those published in the 1970s and 1980s-adopt an approach in which data and observations from particular countries are extrapolated to all countries in the category, leading to conclusions that neglect substantial differences among countries within each of these categories (Moavenzadeh, 1978; Edmonds, 1979; World Bank, 1984). In more recent years, in parallel with greater engagement in the subject by academics from the countries being considered, a more specific approach has become prevalent, with studies that address particular aspects for construction (e.g., labour, safety, credit, corruption, etc.) in specific countries. ${ }^{3}$ Although they contribute to knowledge about particular situations, these more specific studies typically are not positioned within a broader conceptual frame capable of supporting contributions to theory about construction industry development.

The second semantic position is represented by a smaller body of literature focussed on the process of construction industry development. This focus on industrial change characterises seminal work by Turin (1978) and Bon (1992), as well as other studies within the discourse their work has inspired (Drewer, 1980; Wells, 1984; Crosthwaite, 2000; Ruddock and Lopes, 2006; Choy, 2011). However, as described above, the lack of data available to characterise construction industries over time and to compare industries in countries at differing stages of economic development has impeded further progress in this direction.

The uncertain semantic foundations of the subject may be traced back to vague definitions of the concept of development in relation to construction. At its first meeting in 1998, the CIB's Task Group 29 on Construction in Developing Countries formally defined construction industry development as "...a deliberate process to improve capacity and effectiveness of the construction industry..." 
(CIB Task Group 29, 1998). This definition has neither been challenged nor elaborated on in the literature, despite advances in knowledge. What does this "deliberate process" entail and, taking into account the dearth of directly relevant statistics, how might progress be measured? To provide a more effective foundation for research, development in relation to construction should be defined with reference to established concepts about broader economic development and growth. Furthermore, highlighting critical, measurable factors involved in construction industry development would provide firmer sematic foundations and support research into the processes of development in construction.

\section{ECONOMIC DEVELOPMENT AND GROWTH}

Within economics, the terms "development" and "growth" may be "notoriously undefined" (Storper and Walker, 1989: 40), yet they are normally used interchangeably to denote increases in productive capabilities, which may be reflected in expanding output, rising income and a more skilled workforce (Kuznets, 1967). Increased productive capabilities can apply to entire economies or to particular industries. Historically, development and growth have been linked with mechanisation and industrialisation-augmentation of labour with machinery to increase productivity-as explicated in Rostow's stages of economic growth (Dobb, 1946; Rostow, 1971). Within this context, "developing economies" are those in the process of transition from primarily agrarian production to increasing industrial production. In contrast, "developed economies" are characterised by declining industrial production in parallel with increasing contribution of services to national income (Kuznets, 1967; Bon, 1992).

What factors underpin this process of industrialisation and increasing productivity? Within growth theory, investment and technology have been consistently identified as principal factors, albeit with varying relative importance. Classical economics, rooted in the Industrial Revolution, places production and growth at the forefront; Adam Smith's specialisation of production functions heralded new techniques and technologies (Smith, 1776/2010), while Marx prioritised appropriation and investment of surplus production as the principal driver of growth (Marx, 1886/1977). In contrast, neoclassical economics focusses upon exchange and the regulating function of price in markets, giving only marginal attention to issues of production and growth (Storper and Walker, 1989). Despite this focus on markets, capital-output ratios, determined by production technologies and influencing relative levels of investment in labour and capital, are an important neoclassical contribution to growth theory (Harris, 1978). Keynes refocussed attention on production by addressing relationships between public investment and increased consumption (Keynes, 1936), leading to the Harrod-Domar growth model, which positioned capital accumulation as the primary engine of expanded productivity and growth (Harrod, 1939; Domar, 1946). However, the Harrod-Domar model neglects diminishing returns on capital, which imply an upper limit upon growth arising from investment (Solow, 1957). To surpass these limits, new productivity-enhancing technologies are required to shift production functions outward, thereby establishing new, higher growth ceilings (Solow, 1970). Thus, while investment can support economic growth in 
the medium term, long-term growth requires dissemination of new productivityenhancing technologies.

Investment and technological change are, in turn, facilitated by institutions, such that economic development and institutional development are inextricable. Institutions entail constraints upon behaviour-formal constraints such as laws and regulations, as well as informal constraints such as norms and conventionswhich enhance the predictability and efficiency of transactions (North, 1994). The development of effective, reliable institutions thus promotes investment in capital and new technology, which supports growth.

While growth theory and institutional economics identify factors underpinning economic development, the applied field of development economics provides greater clarity regarding classifications of countries as "developed" or "developing". The academic field of development economicswhich is closely linked with the development assistance provided by government and non-government organisations-approaches development in a holistic manner. Rather than being concerned strictly with the expansion of production capabilities, for development economists and practitioners development usually refers to improved standards of living, encompassing dimensions of health and education as well as productivity. ${ }^{4}$ Thus, in the study of development economics and the practice of development assistance, economic growth is only one component (i.e., one dimension) of economic development.

The three principle dimensions of economic development are reflected in the human development index, which is used to compare development across countries (United Nations Development Programme, 2019). The human development index combines statistics of life expectancy, schooling and gross national income (GNI) per capita. Gradual change and variation among countries and along these dimensions identify a spectrum of development that stands in contrast to the bipolar categories of "developing" and "developed". Nevertheless, for international organisations such as United Nations agencies and the World Bank, categories of economic development and systems of country classification are adopted for purposes of analysis, policy formulation and provision of assistance. The United Nations defines three categories based on "basic economic country conditions": (1) Developed economies, (2) Economies in transition and (3) Developing economies (United Nations, 2018: 139). ${ }^{5}$ The World Bank defines four economy categories based on annual thresholds of GNI per capita: (1) High income, (2) Upper-middle income, (3) Lowermiddle income and (4) Low income. ${ }^{6}$ Rather than suggesting that income and productivity are the primary factors in economic development, this system of country classification reflects a close correlation of income with indicators of health and education. This correlation underpins the standard use of World Bank income categories as an analytic frame within development economics, where "developing countries" generally refers to middle- and low-income economies.

This brief skim across the deep waters of growth theory and development economics provides material for reinforcing semantic foundations of research into construction in developing countries. To align with broader concepts about economic growth and development, development in construction should be defined as the expansion of productive capabilities of the construction industry through increased investment in the medium-term and the dissemination of new technologies in the medium- and long-term. Moreover, standard country classifications can strengthen the definition and focus of this research subject. 
Developing countries (i.e., those in the process of increasing industrial production) are low- and middle-income economies, as per World Bank classification. In addition to clearly delimiting the field of study, positioning economies and their construction industries in relation to GNI could support the identification of relationships between development in construction and broader trajectories of economic development.

\section{DIMENSIONS OF DEVELOPMENT IN CONSTRUCTION}

The definition of development in construction elaborated previously-i.e., the expansion of productive capabilities of construction industries through investment (in the medium term) and the introduction of new technologies (in the long term) -falls short of the stated objective of an instrumental definition that identifies critical, measurable factors. Of these two factors (investment and technology), investment needs for construction industries are clearer, including investment in tools and equipment for on-site construction, machinery and production facilities for production of materials and components, and construction skills. If we assume that long-term development is the primary concern for research and policy, what forms of technologies are relevant to development in construction, and what factors or circumstances will ameliorate their exploitation? In his pioneering work on economic growth, Kuznets identified the adequacy of exploitation of "material and social technologies" as the main distinction between developed and developing economies (Kuznets, 1967: 477). This provides a useful frame for considering technologies that are relevant to growth in construction. Viewed through this frame, literature addressing construction in developing countries highlights critical dimensions to augment the definition of development in construction.

The first of Kuznets' technology categories, "Material technologies", is taken here to refer to physical technological artefacts-e.g., new productivityenhancing materials, components, tools and equipment-together with the skills and expertise required to integrate them within building work. For developing economies, this includes relatively low-tech technologies and techniques that are commonplace in more-developed contexts but have yet to be adequately disseminated, e.g., mechanised concrete mixing and off-site concrete batching. From the literature, two prominent factors emerge that restrict dissemination of these material technologies in developing countries: (1) Availability of materials and equipment, and (2) Availability of expertise.

In relation to the first factor-availability of materials and equipmentnumerous studies have highlighted the inadequate domestic manufacture of construction materials and components as a significant limitation on industrial development (World Bank, 1984; Hillebrandt, 2000; Ofori, 2006; Yamunaqué and Ruiz, 2006). Although the domestic manufacture of materials, components and equipment may increase the availability of some material technologies, importation will be required for many patented technologies or those involving manufacturing capabilities which are not available domestically. Increased availability and exploitation of material construction technologies in developing economies thus requires both greater scope of domestic manufacturing and improved access to imported technological goods. 
In relation to the second factor, "Availability of expertise", numerous studies have identified a surplus of labour for construction in developing countries (Hillebrandt, 1999; ILO [International Labour Organisation], 2001; Wells, 2006). The literature has also identified a typical scarcity of trade, managerial and professional expertise limiting construction industry development and undermining individual projects (World Bank, 1984; Kirmani and Baum, 1992; Serpell and Ferrada, 2006; Rwelamila, 2012; Ellis, Nyuur and Yaw, 2012). This disjunction between a surplus of labour and a scarcity of expertise was highlighted in a survey of 3,300 construction workers in Sri Lanka, which identified a shortage of specialist skills despite $60 \%$ of the skilled labour force being under-utilised (Jayawardane and Gunawardena, 1998). While rapidly urbanising populations could provide sufficient basic labour for construction, inadequate education and training underpins the lack of the expertise required to exploit material construction technologies.

Thus, inadequate dissemination of material construction technologies in developing countries may be considered in relation to the availability of two groups of construction resources: (1) Materials, components and equipment, and (2) Skilled or expert labour. The availability of a third resource, credit (or working finance) for contractors, is highlighted in the literature as another significant constraint on construction industry development.

Credit is neither a factor of production nor is it directly employed in the construction process; thus, it is not usually considered a construction resource. However, typical production arrangements, whereby other resources are purchased and integrated in built work prior to payment by clients, result in credit being a necessary resource for construction contracting (Hillebrandt, 2000: 104). Insufficient access to credit for construction firms has been identified in numerous studies as a typical constraint upon industry development, underpinned by the lack of information for creditors to evaluate risks and a lack of collateral of small construction firms to secure loans (Moavenzadeh, 1978; World Bank, 1984; Eyiah, 2001; Palliyaguru, Amaratunga and Rameezdeen, 2006; Aibinu and Odeyinka, 2006; Shakantu, 2012). Thus, insufficient access of contractors to formal credit appears to be common and may be attributed to inadequacies in: (1) Administrative and managerial expertise among construction firms, (2) Systems that enable potential creditors to assess risks and (3) Systems to enforce loan repayments.

The second technology category identified by Kuznets, "Social technologies", here refers to the systems through which actors involved in construction are organised, such as systems of communication, licensing, registration, certification, procurement and contracting. Two prominent factors have emerged from the literatures which undermine exploitation of these systems in developing countries: quality of regulation (i.e., public administration) and reliability of legal frames.

Quality of regulation refers here to the capability of branches of government to formulate and implement systems pertaining to, for example, professional licencing, firm registration, technical standards, construction codes and certification. Numerous studies have highlighted poor regulation of construction, attributing it to inadequate bureaucratic capabilities (World Bank, 1984; Imbert, 1990; Fox, Scott and Neale, 1999; Uriyo and Muhegi, 2003) and inappropriate regulations (World Bank, 1984; Ofori, 2006). One implication of poor regulation is that many construction firms in developing countries operate informally 
(i.e., outside systems of registration and taxation) which restricts training and investment, thus undermining industry development (ILO, 2001; Wells, 2007; 2012).

Reliability of legal frames refers here to the effectiveness and efficiency with which statutory authorities, courts of law and systems of arbitration can enforce contractual responsibilities and resolve contractual disputes, thereby reducing risks and transaction costs and supporting the organisation of firms in project coalitions. Numerous studies have highlighted the lack of reliable legal frames for procurement and contracting in many developing countries (World Bank, 1984; Ofori, 1999, 2006). Practical implications of unreliable legal frames include a lack of effective dispute resolution and limited enforceability of construction contracts (Ullal, 2018). Delayed contract payments are a common outcome identified in the literature (Kirmani, 1988; Alinaitwe, Apolot and Tindiwensi, 2013; Marzouk and El-Rasas, 2014), with implications including increased contracting risk, reduced investment and stifled industry development.

Thus, inadequate functioning of the systems through which construction is organised in developing countries can be considered in relation to the two prominent factors in the literature mentioned above, which are also aspects of governance: quality of regulation and reliability of legal frames. Both factors relate to the function of public institutions (e.g., bureaucracies, courts of law and statutory authorities). A third condition related to the function of public institutions, the "Prevalence of corruption", has also been highlighted in the literature as an important constraint upon construction industry development.

Corruption in construction arises from the roles that governments play as regulators and clients. Many studies have identified a relatively high prevalence of corruption in relation to construction in developing economies (Tanzi and Davoodi, 1998; Kenny, 2007, 2010; Sohail and Cavill, 2008; Ofori, 2012), suggesting that corruption is widespread in construction sectors and that the long-term costs (e.g., costs associated with prioritising new construction over maintenance and increased maintenance costs due to undermined construction quality) exceed the short-term costs of inflated contract prices (Tanzi and Davoodi, 1998). While some of the literature has addressed corruption in construction in a general manner, other studies have highlighted the constraining impacts of corruption in particular countries, such as India (Tabish and Jha, 2012), South Africa (Bowen, Edwards and Cattell, 2012) and Ghana (Ameyaw et al., 2017).

Six important factors affecting development in construction thus emerge from the literature: (1) Availability of materials, components and equipment, (2) Availability of expertise, (3) Availability of credit for contractors, (4) Quality of regulation, (5) Reliability of legal frames and (6) Prevalence of corruption. These dimensions allow the definition of development in construction to be elaborated in a manner similar to how economic development is defined through reference to dimensions of health, education and productivity. Long-term development in construction may thus be considered a process of increasing productive capabilities through dissemination of productivity-enhancing technologies, all supported by the amelioration of these six dimensions. In order to advance theory and contributions to practice, the study of development in construction should be concerned with identifying patterns and ameliorating strategies in relation to these dimensions, within countries over time and across countries at different stages of economic development. 


\section{CORRELATES OF DEVELOPMENT IN CONSTRUCTION}

Identifying patterns across countries and within countries over time in relation to the six dimensions of development in construction requires measurement and quantitative comparisons. However, such measurement and comparisons are impeded by the lack of statistics describing construction industries, leading to the prevalence of case-based studies that describe particular aspects of construction in specific situations. Despite this lack of directly relevant statistics, potential statistical correlates from a variety of databases can describe indirectly the six dimensions of construction industry development for a sufficient range of countries. National accounts data compiled by the United Nations Statistics Division and national employment data compiled by the ILO include data that are not intended to describe inputs for construction but can provide useful indirect descriptions (United Nations Statistics Division, 2019; ILO, 2019). The Enterprise Surveys and the Doing Business Project of the World Bank compile statistics that describe various aspects of national business environments, which can also apply to economic and institutional environments of construction projects (World Bank, 2019a, 2019b). The World Development Indicators is a compendium of statistical indicators, some of which are relevant to construction (World Bank, 2019c). The Worldwide Governance Indicators describe national institutional conditions, which can also apply to institutional conditions surrounding construction (World Bank, 2019d). Although the statistics from these sources do not describe directly the six dimensions of construction development, they provide useful proxies in the absence of more accurate data.

The accuracy or utility of any proxy indicator as a correlate of a particular dimension of development in construction can be considered in relation to two factors: relevance and objectivity. "Relevance" refers here to the conceptual distance between the potential correlate and the actual dimension to be measured. For example, take two alternative proxies used to describe amounts of manufacturing of construction materials and components: either value-added by manufacturing (VAM) (a general description of manufacturing) or cement production statistics. Taking into account the wide range of manufactured materials and components used in construction, VAM is more relevant in this example due to the inordinate specificity of cement production data.

"Objectivity" refers here to the degree of objectivity characterising the sources and data collection methods from which the statistics are derived. The sources and collection methods employed in the databases described above can be divided into three categories: (1) National accounts and other official sources, (2) Observer surveys and (3) Participant surveys. Statistics in the first category, i.e., those derived from national accounts and other official sources, are considered here to be the most objective of the three categories (e.g., valueadded data compiled by the United Nations Statistics Division and employment data compiled by the ILO). ${ }^{7}$ The second category, observer surveys, characterise the data collection methods employed in the Worldwide Governance Indicators and the World Bank's Country Policy and Institutions Assessment (CPIA), which involve expert respondents such as World Bank and government officials, nongovernment organisations and academics. Statistics in this category are regarded here as less objective than those derived from national accounts and official sources. Statistics in the third category, those derived from participant surveys, are gathered from respondents who are directly involved in the issues under 
investigation, such as the survey of firms in the World Bank's Enterprise Surveys and the Doing Business Project. Statistics derived from participant surveys are regarded here as being the least objective of the three categories.

A range of indicators relevant to each of the dimensions of development are presented in Table 1. Assessments of "relevance and objectivity" are noted for each indicator. For example, the indicator "Percentage of firms choosing inadequately educated workforce as their biggest obstacle" is noted in Table 1 as having low objectivity because it is based upon participant surveys and it involves respondents subjectively comparing this obstacle to other obstacles. In comparison, the indicator "Proportion of inputs that are of foreign origin" is identified in Table 1 as having moderate objectivity because, although it is also derived from participant surveys, the answers involve quantitative rather than subjective assessments. Indicators based on data collected through official administrative systems, such as employment distribution by education and VAM are identified in Table 1 as having high objectivity.

Table 1. Statistical indicators of six dimensions of development in construction

\begin{tabular}{|c|c|c|c|c|}
\hline Dimension & Indicator & Source & Relevance & Objectivity \\
\hline \multirow[t]{5}{*}{$\begin{array}{l}\text { Availability } \\
\text { of expertise }\end{array}$} & $\begin{array}{l}\text { Employment distribution } \\
\text { by education: } \\
\text { Advanced education } \\
\text { (percentage of working } \\
\text { age population) }\end{array}$ & ILO (2019) & $\begin{array}{c}\text { High } \\
\text { (Professional } \\
\text { expertise) }\end{array}$ & High \\
\hline & $\begin{array}{l}\text { Employment distribution } \\
\text { by education: } \\
\text { Intermediate education } \\
\text { (percentage of working } \\
\text { age population) }\end{array}$ & ILO (2019) & $\begin{array}{l}\text { Medium } \\
\text { (Managerial } \\
\text { and trade } \\
\text { expertise) }\end{array}$ & High \\
\hline & $\begin{array}{l}\text { Percentage of firms } \\
\text { choosing inadequately } \\
\text { educated workforce } \\
\text { as biggest obstacle }\end{array}$ & $\begin{array}{l}\text { World Bank } \\
\text { (2019a) }\end{array}$ & High & $\begin{array}{c}\text { Low } \\
\text { (Participant } \\
+ \text { Subjective } \\
\text { question) }\end{array}$ \\
\hline & $\begin{array}{l}\text { Percentage of firms } \\
\text { identifying an } \\
\text { inadequately educated } \\
\text { workforce as a major } \\
\text { constraint }\end{array}$ & $\begin{array}{l}\text { World Bank } \\
\text { (2019a) }\end{array}$ & High & $\begin{array}{l}\text { Low } \\
\text { (Participant } \\
+ \text { Subjective } \\
\text { question) }\end{array}$ \\
\hline & $\begin{array}{l}\text { Proportion of workers } \\
\text { offered formal training }\end{array}$ & $\begin{array}{l}\text { World Bank } \\
\text { (2019a) }\end{array}$ & Medium & $\begin{array}{c}\text { Mid } \\
\text { (Participant } \\
+ \text { Objective } \\
\text { question) }\end{array}$ \\
\hline
\end{tabular}


Table 1. Continued

\begin{tabular}{|c|c|c|c|c|}
\hline Dimension & Indicator & Source & Relevance & Objectivity \\
\hline \multirow[t]{6}{*}{$\begin{array}{l}\text { Availability of } \\
\text { materials and } \\
\text { equipment }\end{array}$} & $\begin{array}{l}\text { Manufacturing, value } \\
\text { added (percentage of } \\
\text { GDP) }\end{array}$ & $\begin{array}{l}\text { World Bank } \\
(2019 c)\end{array}$ & $\begin{array}{c}\text { Medium } \\
\text { (Domestic } \\
\text { manufacturing) }\end{array}$ & High \\
\hline & $\begin{array}{l}\text { Hydraulic cement, } \\
\text { world production, by } \\
\text { country }\end{array}$ & $\begin{array}{l}\text { USGS (US } \\
\text { Geological } \\
\text { Survey) } \\
(2019)\end{array}$ & $\begin{array}{c}\text { Low } \\
\text { (Domestic } \\
\text { manufacturing) }\end{array}$ & High \\
\hline & $\begin{array}{l}\text { Proportion of total inputs } \\
\text { that are of foreign origin }\end{array}$ & $\begin{array}{l}\text { World Bank } \\
\text { (2019a) }\end{array}$ & $\begin{array}{l}\text { Medium } \\
\text { (Importation) }\end{array}$ & $\begin{array}{c}\text { Medium } \\
\text { (Participant } \\
\text { + Objective } \\
\text { question) }\end{array}$ \\
\hline & $\begin{array}{l}\text { Trading across borders: } \\
\text { Score }\end{array}$ & $\begin{array}{l}\text { World Bank } \\
\text { (2019b) }\end{array}$ & $\begin{array}{c}\text { Medium } \\
\text { (Importation) }\end{array}$ & $\begin{array}{c}\text { Medium } \\
\text { (Participant } \\
+ \text { Moderated } \\
\text { scores) }\end{array}$ \\
\hline & $\begin{array}{l}\text { Logistics performance } \\
\text { index: Overall score }\end{array}$ & $\begin{array}{l}\text { World Bank } \\
\text { (2019f) }\end{array}$ & $\begin{array}{c}\text { Medium } \\
\text { (Importation) }\end{array}$ & $\begin{array}{c}\text { Medium } \\
\text { (Participant } \\
+ \text { Moderated } \\
\text { scores) }\end{array}$ \\
\hline & $\begin{array}{l}\text { Logistics performance } \\
\text { index: Quality of trade } \\
\text { and transport-related } \\
\text { infrastructure (score) }\end{array}$ & $\begin{array}{l}\text { World Bank } \\
\text { (2019f) }\end{array}$ & $\begin{array}{c}\text { Medium } \\
\text { (Importation) }\end{array}$ & $\begin{array}{c}\text { Medium } \\
\text { (Participant } \\
+ \text { Moderated } \\
\text { scores) }\end{array}$ \\
\hline \multirow[t]{5}{*}{$\begin{array}{l}\text { Availability } \\
\text { of credit for } \\
\text { contractors }\end{array}$} & $\begin{array}{l}\text { Domestic credit to } \\
\text { private sector by banks } \\
\text { (percentage of GDP) }\end{array}$ & $\begin{array}{l}\text { World Bank } \\
(2019 \mathrm{c})\end{array}$ & High & High \\
\hline & $\begin{array}{l}\text { Domestic credit } \\
\text { to private sector } \\
\text { (percentage of GDP) }\end{array}$ & $\begin{array}{l}\text { World Bank } \\
(2019 \mathrm{c})\end{array}$ & High & High \\
\hline & $\begin{array}{l}\text { Percentage of firms with } \\
\text { a bank loan or line of } \\
\text { credit }\end{array}$ & $\begin{array}{l}\text { World Bank } \\
\text { (2019a) }\end{array}$ & High & $\begin{array}{c}\text { Medium } \\
\text { (Participant } \\
\text { + Objective } \\
\text { question) }\end{array}$ \\
\hline & $\begin{array}{l}\text { Percentage of firms } \\
\text { using banks to finance } \\
\text { working capital }\end{array}$ & $\begin{array}{l}\text { World Bank } \\
\text { (2019a) }\end{array}$ & High & $\begin{array}{l}\text { Medium } \\
\text { (Participant } \\
\text { + Objective } \\
\text { question) }\end{array}$ \\
\hline & $\begin{array}{l}\text { Proportion of working } \\
\text { capital financed by } \\
\text { banks }\end{array}$ & $\begin{array}{l}\text { World Bank } \\
\text { (2019a) }\end{array}$ & High & $\begin{array}{l}\text { Medium } \\
\text { (Participant } \\
+ \text { Objective } \\
\text { question) }\end{array}$ \\
\hline
\end{tabular}


Table 1. Continued

\begin{tabular}{|c|c|c|c|c|}
\hline Dimension & Indicator & Source & Relevance & Objectivity \\
\hline & $\begin{array}{l}\text { Percentage of firms } \\
\text { identifying access to } \\
\text { finance as a major } \\
\text { constraint }\end{array}$ & $\begin{array}{l}\text { World Bank } \\
\text { (2019a) }\end{array}$ & High & $\begin{array}{l}\text { Low } \\
\text { (Participant } \\
+ \text { Subjective } \\
\text { question) }\end{array}$ \\
\hline \multirow[t]{8}{*}{$\begin{array}{l}\text { Quality of } \\
\text { regulation }\end{array}$} & $\begin{array}{l}\text { Government } \\
\text { effectiveness: Estimate }\end{array}$ & $\begin{array}{l}\text { World Bank } \\
\text { (2019d) }\end{array}$ & High & $\begin{array}{c}\text { Medium } \\
\text { (Expert survey) }\end{array}$ \\
\hline & $\begin{array}{l}\text { Regulatory quality: } \\
\text { Estimate }\end{array}$ & $\begin{array}{l}\text { World Bank } \\
\text { (2019d) }\end{array}$ & High & $\begin{array}{c}\text { Medium } \\
\text { (Expert survey) }\end{array}$ \\
\hline & $\begin{array}{l}\text { Days to obtain a } \\
\text { construction-related } \\
\text { permit }\end{array}$ & $\begin{array}{l}\text { World Bank } \\
\text { (2019a) }\end{array}$ & Medium & $\begin{array}{l}\text { Medium } \\
\text { (Participant } \\
+ \text { Objective } \\
\text { question) }\end{array}$ \\
\hline & $\begin{array}{l}\text { Percentage of firms } \\
\text { choosing business } \\
\text { licensing and permits as } \\
\text { their biggest obstacle }\end{array}$ & $\begin{array}{l}\text { World Bank } \\
\text { (2019a) }\end{array}$ & High & $\begin{array}{l}\text { Low } \\
\text { (Participant } \\
\text { + Subjective } \\
\text { question) }\end{array}$ \\
\hline & $\begin{array}{l}\text { Percentage of firms } \\
\text { choosing business } \\
\text { licensing and permits as } \\
\text { a major constraint }\end{array}$ & $\begin{array}{l}\text { World Bank } \\
\text { (2019a) }\end{array}$ & High & $\begin{array}{l}\text { Low } \\
\text { (Participant } \\
\text { + Subjective } \\
\text { question) }\end{array}$ \\
\hline & $\begin{array}{l}\text { Quality of public } \\
\text { administration rating }\end{array}$ & $\begin{array}{l}\text { World Bank } \\
\text { (2019e) }\end{array}$ & High & $\begin{array}{c}\text { Medium } \\
\text { (Expert survey) }\end{array}$ \\
\hline & $\begin{array}{l}\text { Dealing with } \\
\text { construction permits: } \\
\text { Score }\end{array}$ & $\begin{array}{l}\text { World Bank } \\
\text { (2019b) }\end{array}$ & Medium & $\begin{array}{c}\text { Medium } \\
\text { (Participant } \\
+ \text { Objective } \\
\text { question) }\end{array}$ \\
\hline & $\begin{array}{l}\text { Dealing with } \\
\text { construction permits: } \\
\text { Quality control after } \\
\text { construction - Index }\end{array}$ & $\begin{array}{l}\text { World Bank } \\
\text { (2019b) }\end{array}$ & Medium & $\begin{array}{c}\text { Medium } \\
\text { (Participant } \\
\text { + Objective } \\
\text { question) }\end{array}$ \\
\hline \multirow[t]{3}{*}{$\begin{array}{l}\text { Reliability of } \\
\text { legal frame }\end{array}$} & Rule of law: Estimate & $\begin{array}{l}\text { World Bank } \\
\text { (2019d) }\end{array}$ & High & $\begin{array}{c}\text { Medium } \\
\text { (Expert survey) }\end{array}$ \\
\hline & $\begin{array}{l}\text { Percentage of firms } \\
\text { identifying the courts } \\
\text { system as a major } \\
\text { constraint }\end{array}$ & $\begin{array}{l}\text { World Bank } \\
\text { (2019a) }\end{array}$ & High & $\begin{array}{l}\text { Low } \\
\text { (Participant } \\
+ \text { Subjective } \\
\text { question) }\end{array}$ \\
\hline & $\begin{array}{l}\text { CPIA property rights and } \\
\text { rule-based governance } \\
\text { rating }\end{array}$ & $\begin{array}{l}\text { World Bank } \\
(2019 e)\end{array}$ & High & $\begin{array}{c}\text { Medium } \\
\text { (Expert survey) }\end{array}$ \\
\hline
\end{tabular}


Table 1. Continued

\begin{tabular}{|c|c|c|c|c|}
\hline \multirow[t]{5}{*}{ Dimension } & Indicator & Source & Relevance & Objectivity \\
\hline & $\begin{array}{l}\text { Enforcing contracts: } \\
\text { Score }\end{array}$ & $\begin{array}{l}\text { World Bank } \\
\text { (2019b) }\end{array}$ & Medium & $\begin{array}{c}\text { Medium } \\
\text { (Participant } \\
+ \text { Moderated } \\
\text { scores) }\end{array}$ \\
\hline & $\begin{array}{l}\text { Enforcing contracts: } \\
\text { Days }\end{array}$ & $\begin{array}{l}\text { World Bank } \\
\text { (2019b) }\end{array}$ & Medium & $\begin{array}{l}\text { Medium } \\
\text { (Participant } \\
+ \text { Objective } \\
\text { question) }\end{array}$ \\
\hline & $\begin{array}{l}\text { Enforcing contracts: } \\
\text { Quality of the judicial } \\
\text { processes index: Score }\end{array}$ & $\begin{array}{l}\text { World Bank } \\
\text { (2019b) }\end{array}$ & Medium & $\begin{array}{l}\text { Low } \\
\text { (Participant } \\
+ \text { Subjective } \\
\text { question) }\end{array}$ \\
\hline & $\begin{array}{l}\text { Getting credit: Strength } \\
\text { of legal rights index: } \\
\text { Score }\end{array}$ & $\begin{array}{l}\text { World Bank } \\
\text { (2019b) }\end{array}$ & Medium & $\begin{array}{c}\text { Medium } \\
\text { (Participant } \\
+ \text { Moderated } \\
\text { scores) }\end{array}$ \\
\hline \multirow[t]{6}{*}{$\begin{array}{l}\text { Control of } \\
\text { corruption }\end{array}$} & $\begin{array}{l}\text { Control of corruption: } \\
\text { Estimate }\end{array}$ & $\begin{array}{l}\text { World Bank } \\
\text { (2019d) }\end{array}$ & High & $\begin{array}{c}\text { Medium } \\
\text { (Expert survey) }\end{array}$ \\
\hline & $\begin{array}{l}\text { Bribery index } \\
\text { (percentage of gift } \\
\text { or informal payment } \\
\text { requests during public } \\
\text { transactions) }\end{array}$ & $\begin{array}{l}\text { World Bank } \\
\text { (2019a) }\end{array}$ & High & $\begin{array}{l}\text { Medium } \\
\text { (Participant } \\
+ \text { Objective } \\
\text { question) }\end{array}$ \\
\hline & $\begin{array}{l}\text { Percentage of firms } \\
\text { identifying corruption as } \\
\text { a major constraint }\end{array}$ & $\begin{array}{l}\text { World Bank } \\
\text { (2019a) }\end{array}$ & High & $\begin{array}{c}\text { Low } \\
\text { (Participant } \\
+ \text { Subjective } \\
\text { question) }\end{array}$ \\
\hline & $\begin{array}{l}\text { Percentage of firms } \\
\text { expected to give gifts } \\
\text { to get a construction } \\
\text { permit }\end{array}$ & $\begin{array}{l}\text { World Bank } \\
\text { (2019a) }\end{array}$ & Medium & $\begin{array}{c}\text { Medium } \\
\text { (Participant } \\
\text { + Objective } \\
\text { question) }\end{array}$ \\
\hline & $\begin{array}{l}\text { Percentage of firms } \\
\text { expected to give gifts } \\
\text { to secure government } \\
\text { contract }\end{array}$ & $\begin{array}{l}\text { World Bank, } \\
(2019 a)\end{array}$ & High & $\begin{array}{c}\text { Medium } \\
\text { (Participant } \\
+ \text { Objective } \\
\text { question) }\end{array}$ \\
\hline & $\begin{array}{l}\text { Transparency, } \\
\text { accountability and } \\
\text { corruption in the public } \\
\text { sector rating }\end{array}$ & $\begin{array}{l}\text { World Bank } \\
(2019 e)\end{array}$ & High & $\begin{array}{c}\text { Medium } \\
\text { (Expert survey) }\end{array}$ \\
\hline
\end{tabular}


These correlates provide a means to compare construction industry development in country income groups, highlighting patterns of development in construction in relation to changes in national income. From the range of indicators identified in Table 1, the most appropriate indicator(s) for each dimension have been selected and consolidated in Figure 1 in a manner which enables a holistic overview of the dimensions of development in construction for three groups: (1) High-, (2) Middle- and (3) Low-income economies. While presenting the statistics in a novel format, Figure 1 is essentially an agglomeration of standard box plots. Each axis of the radar chart refers to one of the six dimensions of development: (1) Availability of expertise, (2) Availability of materials and equipment, (3) Availability of credit, (4) Regulatory quality, (5) Reliability of the legal frame and (6) Control of corruption. On each axis, the interquartile range for each country income group is shaded and the median value for each group is denoted by a dashed line. The values for each indicator have been normalised such that, for each indicator, they were converted to percentages of the maximum value. For each axis, higher values (i.e., greater distance from the centre) denote better conditions. Linking shaded interquartile ranges of each axis defines a shaded polygon for each income group. By eliminating the upper and lower quartiles, this shaded polygon for each income group represents the middle range of conditions (i.e., the moderate conditions) characterising the level of development in construction.

Several aspects of development in construction are illustrated in Figure 1. First, the path of development in construction reflects that of broader economic development. That is, as income increases from low- to middle- to high-income groups, the general situation regarding each of the six dimensions improves, as reflected in increasing distances of interquartile ranges from the centre. Second, regarding differences between the low- and middle-income groups, an apparent gap between the interquartile ranges regarding availability of expertise and credit contrasts with the substantial overlap of institutional conditions. Thus, with regard to construction, middle- and low-income countries differ more in relation to economic conditions than institutional conditions. Third, significant overlap between low- and middle-income countries in relation to institutional conditions-i.e., regulatory quality, legal reliability and prevalence of corruptionsuggest comparable institutional environments surrounding construction industries in a significant proportion of countries across both categories. Fourth, the gap between middle- and high-income economies is greater with regard to institutional conditions than economic conditions. This difference in institutional conditions suggests that poor institutional capability (rather than inadequate resource availability) is the greater general constraint on development in construction in middle-income countries. 


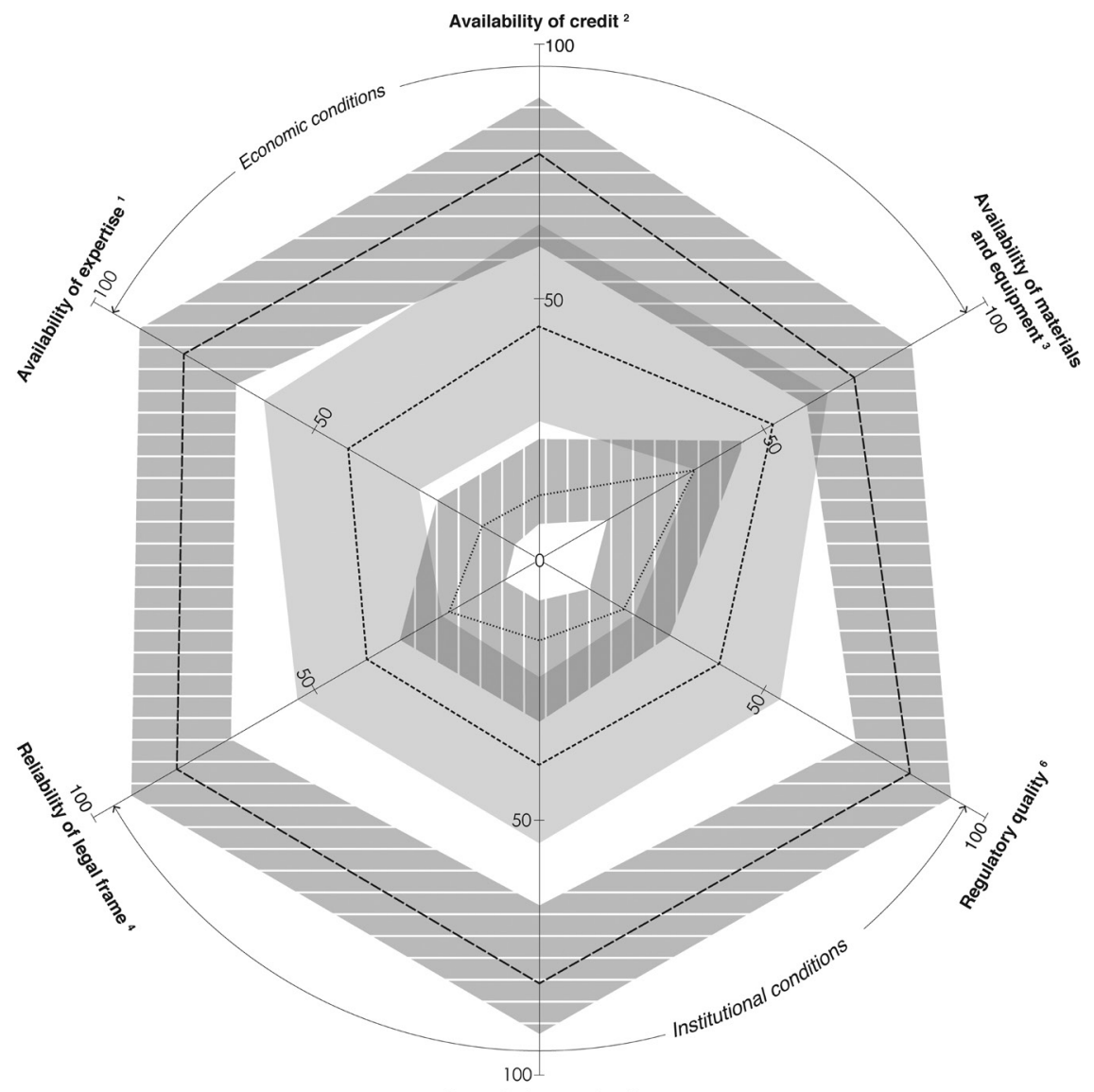

Control of corruption ${ }^{5}$

\begin{tabular}{|c|c|c|}
$\begin{array}{c}\text { Low income } \\
\text { countries } \\
\text { Interquartile range } \\
\text { median }\end{array}$ & $\begin{array}{c}\text { Middle income } \\
\text { countries }^{7}\end{array}$ & $\begin{array}{c}\text { High income }^{7} \\
\text { countries }^{7}\end{array}$ \\
\hline Interquartile range & Interquartile range \\
\hline median & median \\
\hline
\end{tabular}

Figure 1. Dimensions of development in construction: Interquartile ranges and medians for high-, middle- and low-income countries

Notes:

'Percentile rank of the sum of (1) Percentage of workforce (15 to 64 year-olds, both sexes) with intermediate education and (2) Percentage of workforce (15 to 64 year-olds, both sexes) with intermediate education (ILO, 2019).

2Percentile rank of Domestic credit to the private sector by banks as a percentage of GDP (World Bank, 2019d).

${ }^{3}$ Sum of (1) Percentile rank of manufacturing, value added (percentage of GDP) (World Bank, 2019h) and (2) Percentile rank of logistics performance index - overall score (World Bank 2019f). Each percentile rank divided by two, normalising the sum within the range 0-100.

${ }^{4}$ Rule of law - estimate - percentile rank (World Bank, 2019d).

${ }^{5}$ Control of corruption - estimate - percentile rank (World Bank, 2019d).

${ }^{6}$ Regulatory quality - estimate - percentile rank (World Bank, 2019d).

${ }^{7}$ Low income $=2018 \mathrm{GNI}$ per capita < USD 1,025; middle income = 2018 GNI per capita USD 1,026 to USD 12,375; high income $=2018 \mathrm{GNI}$ per capita $>$ USD12,375. 
This graphic consolidation and presentation of statistics also enables individual countries to be positioned in relation to the income groups and to be compared with each other. The example presented in Figure 2 was created by plotting on each axis the values for three countries: India, Malaysia and Nigeria. These three countries have been selected because they are the most frequent contexts of studies published in the Journal of Construction in Developing Countries over the decade from 2009 to 2018.8 Although each country is in the middle-income group, which suggests comparable levels of economic development, significant differences are apparent in conditions surrounding

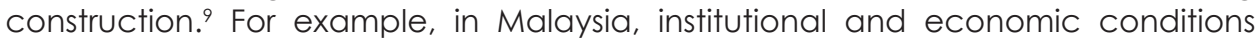
appear to be more conducive to construction compared to those of India and Nigeria. In particular, notwithstanding limitations of the correlates as measures of actual conditions, availability of materials, equipment and credit for contractors appears to be significantly better in Malaysia. Conditions in India fall within or above the interquartile range for middle-income countries, with the exception of availability of expertise, which is low in India compared to the interquartile range of the middle-income group. With regard to Nigeria, Figure 2 suggests that, notwithstanding a level of availability of expertise, materials and equipment within the interquartile range of the middle-income group, other conditions surrounding construction in Nigeria are more problematic compared to India and Malaysia and to middle-income countries in general. Notably, Figure 2 highlights availability of credit and institutional conditions surrounding construction in Nigeria as particularly problematic. 


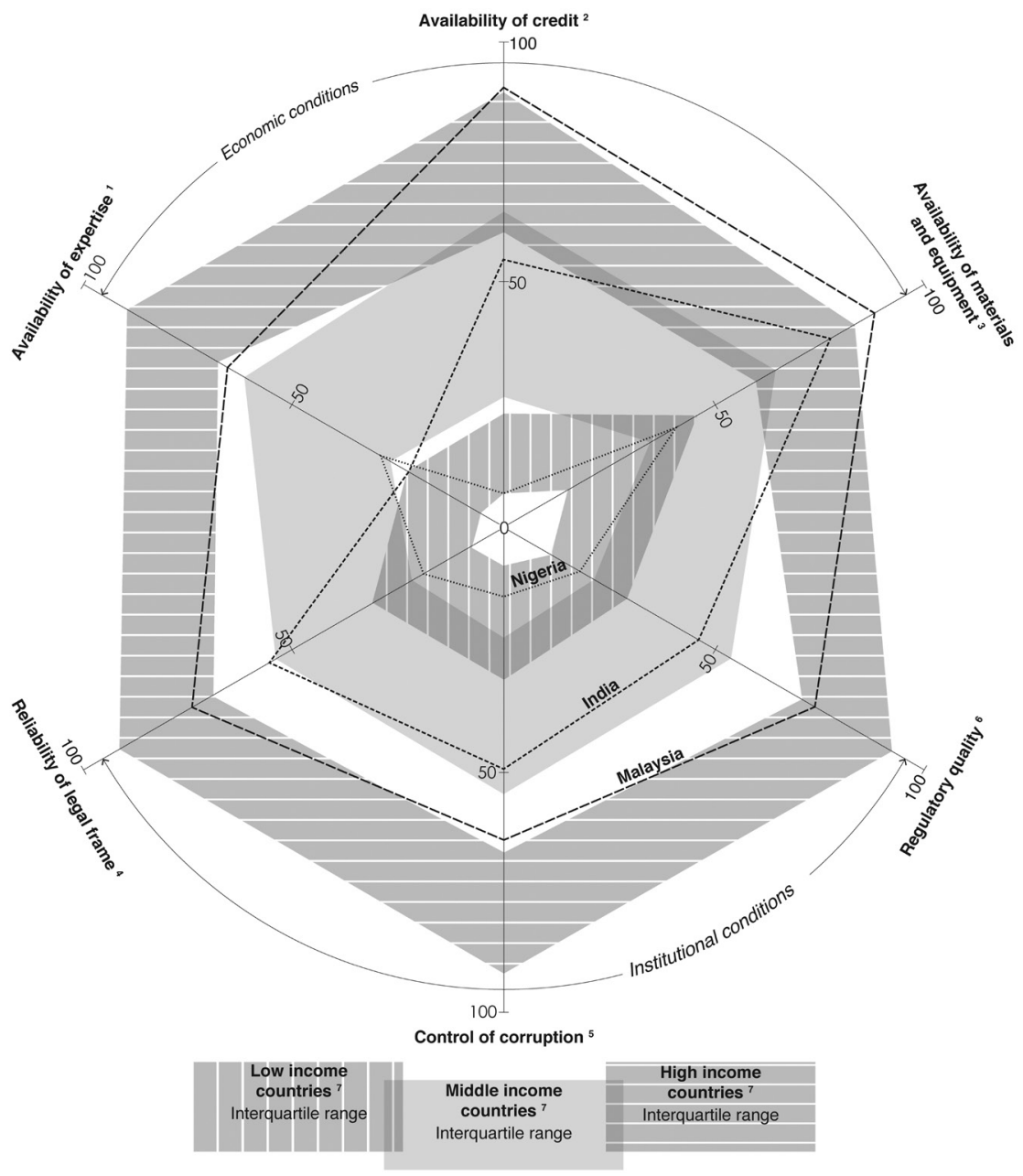

Figure 2. Dimensions of development in construction in India, Malaysia and Nigeria in relation to interquartile ranges for high-, middle- and low-income countries

Notes:

'Percentile rank of the sum of (1) Percentage of workforce (15 to 64 year-olds, both sexes) with intermediate education and (2) Percentage of workforce (15 to 64 year-olds, both sexes) with intermediate education (ILO, 2019).

2Percentile rank of Domestic credit to the private sector by banks as a percentage of GDP (World Bank, 2019d).

${ }^{3}$ Sum of (1) Percentile rank of manufacturing, value added (percentage of GDP) (World Bank, 2019h) and (2) Percentile rank of logistics performance index - overall score (World Bank 2019f). Each percentile rank divided by two, normalising the sum within the range 0-100.

${ }^{4}$ Rule of law - estimate - percentile rank (World Bank, 2019d).

${ }^{5}$ Control of corruption - estimate - percentile rank (World Bank, 2019d).

${ }^{6}$ Regulatory quality - estimate - percentile rank (World Bank, 2019d).

${ }^{7}$ Low income $=2018 \mathrm{GNI}$ per capita $<$ USD 1,025; middle income = 2018 GNI per capita USD 1,026 to USD 12,375; high income $=2018 \mathrm{GNI}$ per capita $>$ USD12,375. 
This method of comparing countries also provides a framework for relating country-specific studies of construction in a manner that can support contributions of individual cases to theory development. As shown in Figure 3, a group of studies that investigated factors contributing to construction project time overruns in different developing countries provides an example of how individual cases from separate studies may be combined. Figure 3 plots on each axis values for three countries that are the subjects of three separate studies: Egypt (Marzouk and El-Rasas, 2014), Uganda (Alinaitwe, Apolot and Tindiwensi, 2013) and Zambia (Kaliba, Muya and Mumba, 2009). Regarding country income categories, Egypt and Zambia are lower-middle-income countries while Uganda is in the lowincome group. ${ }^{10}$ These three countries were selected as they are the subjects of the most-cited studies from the group of "construction project delay" articles published during the 10 years from 2009 to 2018. " These studies ranked the most significant factors causing construction project delays. The five most significant factors identified in each study are:

1. Egypt (Marzouk and El-Rasas, 2014):

a. Finance and payments of completed work by owner,

b. Variation orders/changes of scope by owner during construction,

c. Effects of subsurface conditions (e.g., soil, high water table),

d. Low productivity level of labour and

e. Ineffective planning and scheduling of project.

2. Uganda (Kaliba, Muya and Mumba, 2013):

a. Change of work scope and/or changes in material specifications,

b. Delayed payment to contractors, subcontractors and/or suppliers,

c. Poor monitoring and control, e.g., due to incompetent and/or unreliable supervisors,

d. High inflation, insurance and interest rates and

e. Political insecurity and instability.

3. Zambia (Kaliba, Muya and Mumba, 2009)

a. Delayed payments,

b. Financial process,

c. Financial difficulties,

d. Contract modification and

e. Economic problems. 


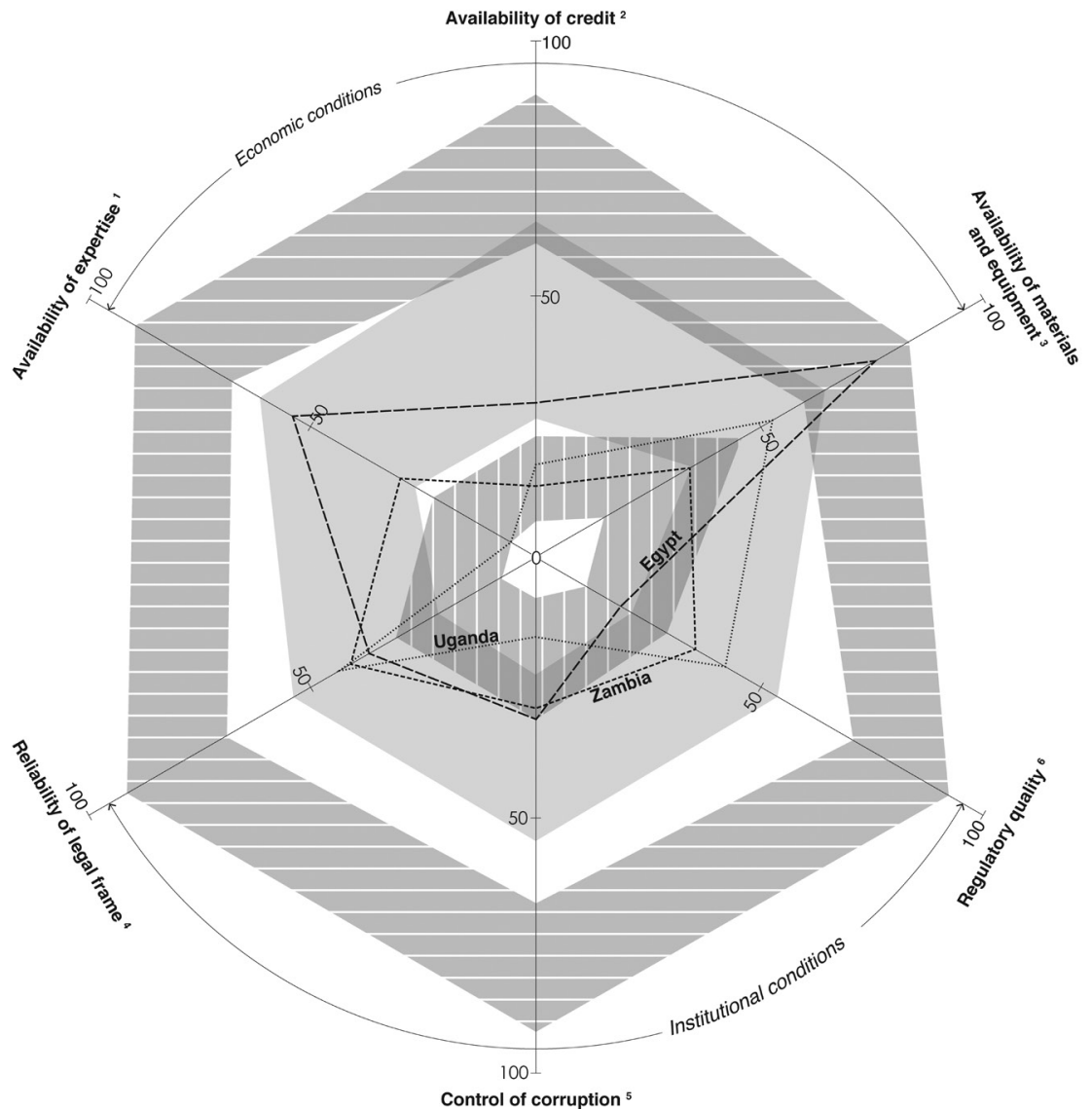

Control of corruption ${ }^{5}$

\begin{tabular}{|c|c|c|}
\hline \multirow{4}{*}{$\begin{array}{c}\text { Low income } \\
\text { countries }{ }^{7} \\
\text { Interquartile range }\end{array}$} & \multirow{4}{*}{$\begin{array}{l}\text { Middle income } \\
\text { countries }^{7} \\
\text { Interquartile range }\end{array}$} & High income \\
\hline & & countries $^{7}$ \\
\hline & & Interquartile range \\
\hline & & \\
\hline
\end{tabular}

Figure 3. Dimensions of development in construction: Egypt, Uganda and Zambia in relation to interquartile ranges for high-, middle- and low-income countries

Notes:

'Percentile rank of the sum of (1) Percentage of workforce (15 to 64 year-olds, both sexes) with intermediate education and (2) Percentage of workforce (15 to 64 year-olds, both sexes) with intermediate education (ILO, 2019).

${ }^{2}$ Percentile rank of Domestic credit to the private sector by banks as a percentage of GDP (World Bank, 2019d).

${ }^{3}$ Sum of (1) Percentile rank of manufacturing, value added (percentage of GDP) (World Bank, 2019h) and (2) Percentile rank of logistics performance index - overall score (World Bank 2019f). Each percentile rank divided by two, normalising the sum within the range 0-100.

${ }^{4}$ Rule of law - estimate - percentile rank (World Bank, 2019d).

${ }^{5}$ Control of corruption - estimate - percentile rank (World Bank, 2019d).

${ }^{6}$ Regulatory quality - estimate - percentile rank (World Bank, 2019d).

'Low income $=2018 \mathrm{GNI}$ per capita < USD 1,025; middle income = 2018 GNI per capita USD 1,026 to USD 12,375; high income $=2018 \mathrm{GNI}$ per capita $>$ USD12,375. 
Considering these causes of project delays in relation to the level of development in construction in each country (measured via the dimensions and correlates) can support conclusions regarding impacts of particular prevailing conditions upon project outcomes. For example, while financial issues and delayed payments are significant causes of delay in each country, the greater significance of financial factors in Zambia (as highlighted in the list)-which has the lowest level of credit availability (as reflected in Figure 3)-could support conclusions connecting project delays to credit availability. Greater prevalence of corruption in Uganda (as reflected in Figure 3) may be connected to the significant impact of political conditions on project delays (as underlined in the list above), suggesting a connection between political instability, corruption and construction project outcomes. In Egypt, better economic conditions compared to Uganda and Zambia stand in contrast to institutional conditions that are similar to, or worse than, those in the other two countries. Such findings require further examination and testing against results of other similar studies addressing construction in different countries. Nevertheless, the analytic frame of dimensions and correlates of development in construction provides a means to position and compare these separate cases.

\section{APPLICATIONS OF THE DIMENSIONS AND CORRELATES}

The relative positioning of case studies and comparison of findings is one way that the framework of dimensions and correlates can contribute to research. Beyond the group of studies addressing construction project time and cost overruns, case studies within other discourses can be positioned in relation to prevailing economic and institutional conditions and thereby in relation to each other. Studies that address national industry characteristics such as determinants of contractor development and typical subcontracting arrangements can also be related within this analytic frame. Thus, country-specific findings that address various aspects of construction projects or industries can be compared in order to build and test theories that relate these characteristics to aspects of industrial development.

The framework can also contribute to research by positioning national cases in relation to categories. Positioning national cases in relation to country income groups can inform and qualify extrapolation of country-specific findings and support the formulation and testing of theories that relate construction industry development to national economic development. Similarly, positioning countryspecific studies in relation to conflict status groups (i.e., groups of peaceful, conflict and post-conflict settings) could support the study of relationships between construction industry development, political stability and national institutional development. Beyond the basic statistical methods and graphic presentation described in this article, the analytic frame of dimensions and correlates can support regression analyses that study in greater detail relationships between construction industry development and national economic and institutional development.

Alongside research applications, the framework can also contribute to policymaking and to project planning and management practices. Positioning construction industry development in individual countries in relation to other countries and categories can highlight particular industrial constraints for further 
investigation and policy intervention. For example, the data illustrated in Figure 3 suggest that poor regulatory quality is a particularly significant constraint on construction industry development in Egypt compared to the other five dimensions and to other middle-income countries. For practitioners, industry constraints highlighted in this manner constitute project risks that may warrant specific planning or management measures. For example, in Figure 3 the identification of the very low availability of expertise and the high prevalence of corruption in Uganda may warrant specific procurement and oversight strategies by international organisations planning infrastructure programs there.

These applications highlight that the framework of dimensions and correlates provides a comparative description rather than an absolute gauge. For each country, a single numeric indicator of construction industry development could be calculated using weighted combinations of the indicators of the six dimensions. However, such an industrial development index would imply an inordinate degree of precision, considering the varied accuracy of the correlates with regard to the dimensions they describe. Notwithstanding limitations on the accuracy of correlates, the framework provides a systematic and useful means of integrating studies and comparing construction industries. While it is relevant to all construction industries, the framework is particularly useful with regard to middle- and low-income countries (i.e., "developing countries") for which direct indicators of industrial productivity are unavailable.

\section{CONCLUSION}

In considering how to energise the study of development in construction, paths forward may be uncovered by looking back. A reassessment of some of the semantic foundations upon which the study of development in construction has been built can assist in strengthening the subject. This includes distinguishing between the study of construction in developing countries vis-à-vis construction industry development. The former suggests application of concepts from the field of construction management-which are typically formulated in relation to developed economies - to the "other" group of developing countries. This entails a focus on category and context. Construction industry development suggests investigation of the "process" of increasing productivity and sophistication of construction industries. These two topics are not mutually exclusive; rather, they are different aspects of the same subject of inquiry. Nevertheless, the greater attention given to categories and context compared to processes of development has contributed to the limited impact of the subject in terms of building theories and making contributions to practice.

Increased attention to the process of development in construction requires that, in addition to its current position within the field of construction management, the subject be positioned in relation to growth theory and development economics. Alignment with growth theory suggests that the study of development in construction should be concerned primarily with increasing productivity through more effective exploitation of productivity-enhancing technologies. This includes both material technologies pertaining inter alia to construction materials, equipment and techniques, and social technologies pertaining to systems through which construction actors are organised. This focus on technology does not imply that innovation and high-tech solutions are 
central to construction industry development in developing economies. On the contrary, most of the productivity-enhancing technologies to be exploited more effectively in developing economies are conventional and relatively low-tech, although they require greater dissemination to enable industry development. By focussing on material and social technologies as well as factors contributing to their dissemination while taking into account existing knowledge from the subject, six critical dimensions of development in construction have been identified: (1) Availability of trade, management and professional expertise, (2) Availability of materials, components and equipment, (3) Availability of credit for construction firms, (4) Quality of regulation, (5) Reliability of legal frames and (6) Prevalence of corruption.

Measurement along these dimensions can position particular construction industries in relation to typical conditions characterising broader groups of economies and in relation to paths of development. While statistical data are not available to describe directly the six dimensions of development in construction, correlates are available that can serve as useful gauges, albeit with varying degrees of appropriateness and accuracy. For each dimension, different statistical correlates are available that involve different degrees of relevance and objectivity. Taken together, these correlates enable comparisons between economies in relation to the environment surrounding construction. These correlates also enable particular construction industries to be positioned in relation to general conditions characterising groups of countries, such as the groups of high-, middle- and low-income countries. This relative positioning can support contributions of country-specific or dimension-specific studies to the formulation of theories describing construction industry development in relation to broader trajectories of national economic development.

\section{NOTES}

1. The CIB Commission 107 on Construction in Developing Countries was originally formulated as Task Group 29, inaugurated at the Working Group 29 Meeting in Arusha, Tanzania. Commission 107 has convened 20 meetings, producing 14 proceedings and four special reports.

2. Input-output tables compiled and published by the Organisation of Economic Cooperation and Development (OECD) have been used in studies describing construction productivity and links between construction and other industries (Bon and Pietroforte, 1990; Bon, Birgonul and Ozdogan, 1999; Pietroforte, Bon and Gregori, 2000). The input-output data used by Gregori and Pietroforte (2018) in relation to BRICS is less detailed than that for more-developed economies.

3. A group of studies addressing factors contributing project time and cost over-runs in particular countries using of questionnaire surveys of practitioners is indicative of this case-based approach. These studies examined countryspecific issues affecting Uganda (Alinaitwe, Apolot and Tindiwensi, 2013), Botswana (Ssegawa-Kaggwa, 2013), Thailand (Toor and Ogunlana, 2008), Nigeria (Aibinu and Odeyinka, 2006), Malaysia (Alaghbari et al., 2007), Egypt (El-Razek, Bassioni and Mubarak, 2008), Libya (Shebob et al., 2012), Cambodia (Santoso and Soeng, 2016) and Tanzania (Sambasivan et al., 2017). 
4. The United Nations General Assembly (1997: 1) defined development as "a multi-dimensional undertaking to achieve a higher quality of life for all people".

5. The United Nations system of country classification also includes supplementary categories based on ad-hoc characteristics, such as least-developed countries (LDCS), small island developing countries and land-locked developing countries.

6. For each system, classification of "economies", as opposed to "countries", focusses attention upon quantifiable socio-economic conditions rather than other subjective characteristics of countries, e.g., cultural aspects.

7. Employment data in ILOstat includes data obtained from national household surveys - i.e., participant surveys. Nevertheless, statistics from ILOstat are classified here as having high objectivity due to the rigorous survey and analysis methods employed, which is reflected in the standard use of these statistics as the most reliable source of national employment data covering a wide range of economies.

8. A review of articles published in the Journal of Construction in Developing Countries from 2009 to 2018 identified 20 articles which examined Nigeria, 11 articles that examined India and 10 articles that examined Malaysia (the journal is available at http://web.usm.my/jcdc//).

9. 2018 GNI per capita: India, USD2,020; Malaysia, USD10,460; Nigeria, USD1,960 (World Bank, 2019i).

10. 2018 GNI per capita: Egypt, USD2,800; Uganda, USD620; Zambia, USD1,430 (World Bank, 2019i).

11. Citation data was obtained from Google Scholar (https://scholar.google. com/) and Scopus (https://www.scopus.com/); data from Google Scholar was prioritised, as several studies in the group of articles were published in journals which are not indexed by Scopus. Citations noted in Google Scholar for the selected studies were: Kaliba, Muya and Mumba (2009), 419 citations; Marzouk and El-Rasas (2017), 152 citations; Alinaitwe, Apolot and Tindiwensi, (2013), 145 citations.

\section{REFERENCES}

Aibinu, A.A. and Odeyinka, H.A. (2006). Construction delays and their causative factors in Nigeria. Journal of Construction Engineering and Management, 132(7): 667-677. https://doi.org/10.1061/(ASCE)0733-9364(2006)132:7(667).

Alaghbari, W.E., Razali A., Kadir, M., Salim, A. and Ernawati (2007). The significant factors causing delay of building construction projects in Malaysia. Engineering, Construction and Architectural Management, 14(2): 192-206. https://doi.org/10.1108/09699980710731308.

Alinaitwe, H., Apolot, R. and Tindiwensi, D. (2013). Investigation into the causes of delay and cost overrun in Uganda's public sector construction projects. Journal of Construction in Developing Countries, 18(2): 33-47.

Ameyaw, E.E., Pärn, E., Chan, A.P.C., Owusu-Manu, D.-G., Edwards, D.J. and Darko, A. (2017). Corrupt practices in the construction industry: Survey of Ghanaian experience. Journal of Management in Engineering, 33(6): 05017006. https://doi.org/10.1061/(ASCE)ME.1943-5479.0000555.

Bon, R. (1992). The future of international construction. Habitat International, 16(3): 119-128. https://doi.org/10.1016/0197-3975(92)90068-A. 
Bon, R. and Pietroforte, R. (1990). Historical comparison of construction sectors in the United States, Japan, Italy and Finland using input-output tables. Construction Management and Economics, 8: 233-247. https://doi.org/10 .1080/01446199000000021.

Bon, R., Birgonul, T. and Ozdogan, I. (1999). An input-output analysis of the Turkish construction sector 1973-1990: A note. Construction Management and Economics, 17: 543-551. https://doi.org/10.1080/014461999371169.

Bowen, P.A., Edwards, P.J. and Cattell, K. (2012). Corruption in the South African construction industry: A thematic analysis of verbatim comments from survey participants. Construction Management and Economics, 30(10): 885-901. https://doi.org/10.1080/01446193.2012.711909.

Chan, P. (2019). Construction in the developing world: Where are the alternative frames of thinking? ARCOM Newsletter, 36(1): 5. Available at: http://www .arcom.ac.uk/-docs/newsletter/2019_36-1.pdf [Accessed on 25 May 2019].

Choy, F.C. (2011). Revisiting the "Bon curve". Construction Management and Economics, 29(7): 695-712. https://doi.org/10.1080/01446193.2011.578959.

CIB Task Group 29 (1998). Managing Construction Industry Development in Developing Countries: Report on the First Meeting of the CIB Task Group 29 (TG 29), 21-23 September 1998, Arusha International Conference Centre, Tanzania. Rotterdam, Netherlands: International Council for Research and Innovation in Building and Construction.

Crosthwaite, D. (2000). The global construction market: A cross-sectional analysis. Construction Management and Economics, 18(5): 619-627. https://doi.org/ $10.1080 / 014461900407428$.

Dobb, M. (1946). Studies in the Development of Capitalism. London: George Routledge and Sons.

Domar, E.D. (1946). Capital expansion, rate of growth, and employment. Econometrica, 14(2): 137-147. https://doi.org/10.2307/1905364.

Drewer, S. (1980). Construction and development: A new perspective. Habitat International, 5(3/4): 395-428. https://doi.org/10.1016/0197-3975(80)90028-4.

Edmonds, G. (1979). The construction industry in developing countries. International Labour Review, 118(3): 355-369.

Ellis, L.C., Nyuur, R.B. and Yaw, A.D. (2012). Human resource development in construction. In G. Ofori (ed.), New Perspectives on Construction in Developing Countries. Abingdon, UK: SPON Press, 229-252.

El-Razek, M.E.A., Bassioni, H.A. and Mobarak, A.M. (2008). Causes of delay in building construction projects in Egypt. Journal of Construction Engineering and Management, 134(11): 831-841. https://doi.org/10.1061/(ASCE)0733 $-9364(2008) 134: 11(831)$.

Eyiah, A.K. (2001). An integrated approach to financing small contractors in developing countries: A conceptual model. Construction Management and Economics, 19(5): 511-518. https://doi.org/10.1080/01446193.2001.9709627.

Fox, P.W., Scott, D. and Neale, R. (1999). Construction industry development: A grounded theory approach. Paper presented at the second International Conference on Construction Industry Development and the first Conference of CIB TG29 on Construction in Developing Countries. Gabarone, Botswana, 15-17 November.

Gregori, T. and Pietroforte, R. (2018). An input-output analysis of the construction sector in emerging markets. Construction Management and Economics, 33(2): 134-145. https://doi.org/10.1080/01446193.2015.1021704. 
Harris, D.J. (1978). Capital Accumulation and Income Distribution. Stanford: Stanford University Press.

Harrod, R.F. (1939). An essay in dynamic theory. The Economic Journal, 49(193): 1433. https://doi.org/10.2307/2225181.

Hillebrandt, P. (2000). Economic Theory and the Construction Industry. 3rd Ed. London: Macmillan Press.

. (1999). Choice of technologies and inputs for construction in developing countries. Paper presented at the second International Conference on Construction Industry Development and the first Conference of CIB TG29 on Construction in Developing Countries. Gabarone, Botswana, 15-17 November.

ILO (International Labour Organisation) (2019). Employment by education [updated 30 July 2018]. Available at: http://www.ilo.org/ilostatfiles/ Documents/Excel/MBI_11_EN.xlsx [Accessed on 16 May 2019].

(2001). The Construction Industry in the Twenty-First Century: Its Image, Employment Prospects and Skill Requirements. Geneva: ILO.

Imbert, D.C.I. (1990). Human issues affecting construction in developing countries. Construction Management and Economics, 8(2): 219-228. https://doi.org/ 10.1080/01446199000000018.

Jayawardane, A.K.W. and Gunawardena, N.D. (1998). Construction workers in developing countries: A case study of Sri Lanka. Construction Management and Economics, 16(5): 521-530. https://doi.org/10.1080/014461998372060.

Kaliba, C., Muya, M. and Mumba, K. (2009). Cost escalation and schedule delays in road construction projects in Zambia. International Journal of Project Management, 27(5): 522-531. https://doi.org/10.1016/j.ijproman.2008.07.003.

Kenny, C. (2010). Publishing Construction Contracts and Outcome Details. Washington DC: World Bank.

(2007). Construction, Corruption, and Developing Countries. Washington DC: World Bank.

Keynes, J.M. (1936). The General Theory of Employment, Interest and Money. London: Macmillan.

Kirmani, S.S. (1988). The Construction Industry in Development. Washington DC: World Bank.

Kirmani, S.S. and Baum, W.C. (1992). Consulting Professions in Developing Countries. Washington DC: World Bank.

Kuznets, S. (1967). Modern Economic Growth: Rate, Structure and Spread. New Haven, CT: Yale University Press.

Marx, K. (1886/1977). Capital: A Critique of Political Economy: Volume One. Trans. by B. Fowkes. New York: Vintage Books.

Marzouk, M.M. and El-Rasas, T.I. (2014). Analyzing delay causes in Egyptian construction projects. Journal of Advanced Research, 5(1): 49-55. https://doi.org/10.1016/j.jare.2012.11.005.

Moavenzadeh, F. (1978). Construction industry in developing countries. World Development, 6(1): 97-116.

North, D. (1994). Economic performance through time. The American Economic Review, 84(3): 359-368.

Ofori, G. (2019). Reflection by Professor George Ofori, London South Bank University. ARCOM Newsletter, 36(1): 6. Available at: http://www.arcom.ac .uk/-docs/newsletter/2019_36-1.pdf [Accessed on 25 May 2019]. 
(2018). Construction in developing countries: Need for new concepts. Journal of Construction in Developing Countries, 23(2):1-6. https://doi.org/ 10.21315/jcdc2018.23.2.1.

(2012). Transparency in construction. In Contemporary Issues in Construction in Developing Countries. Abingdon, UK: SPON Press, 83-124.

. (2006). Improving the construction industry in declining developing economies. Construction Management and Economics, 2(2): 127-132. https://doi.org/10.1080/01446198400000012.

. (1999). Challenges of construction industries in developing countries: Lessons from various countries. Paper presented at the Second International Conference on Construction Industry Development and the first Conference of CIB TG29 on Construction in Developing Countries. Gabarone, Botswana, 15-17 November.

Palliyaguru, R.S., Amaratunga, R. and Rameezdeen, R. (2006). Financing contractors in developing countries: Impact of mobilization advance payment. Paper presented at the Third International SCRI Symposium. Salford, United Kingdom, 3-4 April.

Pietroforte, R., Bon, R. and Gregori, T. (2000). Regional development and construction in Italy: An input-output analysis, 1959-1992. Construction Management and Economics, 18: 151-159. https://doi.org/10.1080/ 014461900370780.

Rostow, W. (1971). The Stages of Economic Growth. 2nd Ed. Cambridge, UK: Cambridge University Press.

Ruddock, L. and Lopes, J. (2006). The construction sector and economic development: The "Bon curve". Construction Management and Economics, 24(7): 717-723. https://doi.org/10.1080/01446190500435218.

Rwelamila, P.D. (2012). Construction project performance in developing countries. In G. Ofori (ed.), Contemporary Issues in Construction in Developing Countries. Abingdon, UK: SPON Press, 318-346.

Rwelamila, P.D. and Ogunlana, S. (2015). W107: Construction in Developing Countries Research Roadmap; Report for Consultation. Cairo: CIB.

Sambasivan, M., Deepak, T.J., Salim, A.N. and Ponniah, V. (2017). Analysis of delays in Tanzanian construction industry. Engineering, Construction and Architectural Management, 24(2): 308-325. https://doi.org/10.1108/ECAM -09-2015-0145.

Santoso, D.S. and Soeng, S. (2016). Analysing delays of road construction projects in Cambodia: Causes and effects. Journal of Management in Engineering, 32(6): 05016020 . https://doi.org/10.1061/(ASCE)ME.1943-5479.0000467.

Serpell, A. and Ferrada, X. (2006). A competency framework for construction supervisors in developing countries. Paper presented at the CIB W107 Construction in Developing Countries International Symposium: Construction in Developing Economies - New Issues and Challenges. Santiago, Chile, 1820 January.

Shakantu, W.M. (2012). Contractor development. In G. Ofori (ed.), New Perspectives on Construction in Developing Countries. Abingdon, UK: SPON Press, 253-281.

Shebob, A., Dawood, N., Shah, R.K. and XU, Q. (2012). Comparative study of delay factors in Libyan and the UK construction industry. Engineering, Construction and Architectural Management, 19(6): 688-712. https://doi .org/10.1108/09699981211277577. 
Smith, A. (1776/2010). An Inquiry into the Nature and Causes of the Wealth of Nations. Edited by J.B. Wight. London: Harriman House.

Sohail, M. and Cavill, S. (2008). Does corruption affect construction? Paper presented at CIB W107 Construction in Developing Countries International Symposium: Construction in Developing Countries - Procurement, Ethics and Technology. Trinidad and Tobago, 16-18 January.

Solow, R.M. (1970). Growth Theory: An Exposition. Oxford: Clarendon Press.

(1957). Technical change and the aggregate production function. The Review of Economics and Statistics, 39(3): 312-320. https://doi.org/ $10.2307 / 1926047$.

Ssegawa-Kaggwa, J. (2013). Using a situation analysis to identify the construction industry deficiencies in Botswana. Journal of Construction in Developing Countries, 18(1): 1-18.

Storper, M. and Walker, R. (1989). The Capitalist Imperative. Oxford: Blackwell.

Tabish, S.Z.S. and Jha, K.N. (2012). The impact of anti-corruption strategies on corruption free performance in public construction projects. Construction Management and Economics, 30(1): 21-35. https://doi.org/10.1080/0144619 3.2011 .654128 .

Tanzi, V. and Davoodi, H. (1998). Roads to Nowhere: How Corruption in Public Investment Hurts Growth. Washington DC: International Monetary Fund.

Toor, S.U.R. and Ogunlana, S.O. (2008). Problems causing delays in major construction projects in Thailand. Construction Management and Economics, 26(4): 395-408.

Turin, D.A. (2003). Building as a process. Building Research and Information, 31 (2): 180-187. https://doi.org/10.1080/09613210302002.

(1978). Construction and development. Habitat International, 3(1/2): 33-45. https://doi.org/10.1016/0197-3975(78)90032-2.

Ullal, A. (2018). Clear, hold and build: Conditions and practices characterising construction in conflict and post-conflict settings. PhD diss. University of Melbourne.

United Nations (2018). World Economic Situation and Prospects 2018. New York: United Nations.

United Nations Development Programme (2019). Human Development Report. New York: UNDP. Available at: http://hdr.undp.org/en/content/human -development-index-hdi [Accessed on 27 June 2019].

United Nations General Assembly (1997). Resolution A/RES/51/240: Agenda for Development. General Assembly Resolution 1-61. New York: United Nations.

United Nations Statistics Division (2019). National accounts official country data. Available at: http://data.un.org/Explorer.aspx [Accessed on 27 June 2019].

Uriyo, A.G. and Muhegi, B.C. (2003). A sustainable regulatory and development framework for a developing country. In G. Ofori and F.Y.Y. Ling (eds.), Knowledge Construction: Proceedings of the Joint International Symposium of CIB Working Commissions. Singapore: Department of Building, National University of Singapore, 678-689.

USGS (US Geological Survey) (2019). Hydraulic cement production by country or locality. Available at: https://prd-wret.s3.us-west-2.amazonaws.com/assets/ palladium/production/atoms/files/myb1-2019-cemen-adv.xlsx [Accessed on 27 June 2019]. 
Wells, J. (2012). Informal construction activity in developing countries. In G. Ofori (ed.), New Perspectives on Construction in Developing Countries. Abingdon, UK: SPON Press, 166-182. . (2007). Informality in the construction sector in developing countries. Construction Management and Economics, 25: 87-93. https://doi.org/ 10.1080/01446190600601339.

. (2006). Labour subcontracting in the construction industries of developing countries: An assessment from two perspectives. Journal of Construction in Developing Countries, $11(1)$ : 17-36.

. (1984). The construction industry in the context of development: A new perspective. Habitat International, 8(3/4): 9-28. https://doi.org/10.1016/01973975(84)90040-7.

World Bank (2019a). Enterprise surveys. Available at: https://www.enterprisesurveys .org/content/dam/enterprisesurveys/documents/DataDetails.xls [Accessed on 11 May 2019].

(2019b). Doing business project. Available at: https://www .doingbusiness.org/content/dam/doingBusiness/excel/Historical-data--complete-data-with-scores.xlsx [Accessed on 9 May 2019].

. (2019c). World development indicators. Available at: http://databank .worldbank.org/data/download/WDI_excel.zip [Accessed on 19 June 2019].

(2019d). World governance indicators. Available at: http://info .worldbank.org/governance/wgi/\#home [Accessed on 19 June 2019].

(2019e). Country policy and institutions assessment. Available at: http://databank.worldbank.org/data/download/CPIA_excel.zip [Accessed on 1 June 2019].

(2019f). Logistics performance index. Available at: https://lpi.worldbank .org/sites/default/files/International_LPI_from_2007_to_2018.xlsx [Accessed on 27 June 2019].

(2019g). World Bank open data: Domestic credit from banks to the private sector (percentage of GDP). Available at: http://api.worldbank.org/ v2/en/indicator/FS.AST.PRVT.GD.ZS? downloadformat=excel [Accessed on 27 June 2019].

(2019h). Manufacturing, value added (percentage of GDP). Available at: http://api.worldbank.org/v2/en/indicator/NV.IND.MANF.ZS? downloadformat=excel [Accessed on 27 June 2019].

(2019i). World development indicators: GNI per capita, Atlas method (current USD). Available at: http://api.worldbank.org/v2/en/ indicator/NY.GNP.PCAP.CD?downloadformat=excel [Accessed on 27 June 2019].

(1984). The Construction Industry: Issues and Strategies in Developing Countries. Washington DC: World Bank.

Yamunaqué, J. and Ruiz, G. (2006). Cost of construction equipment in developing countries. Paper presented at the CIB W107 Construction in Developing Countries International Symposium. Santiago, 18-20 January. Available at: https://www.irbnet.de/daten/iconda/CIB1906.pdf [Accessed on 25 May 2019]. 